\title{
Tendency to Transparency (T3) in general public hospitals' managers
}

\author{
Ebrahim Jaafaripooyan ${ }^{1}$, Ali Mohammad Mosadegh Rad ${ }^{1}$, Maryam Mazinani ${ }^{1 *}$ \\ 1. School of Public Health, Tehran University of Medical Sciences, Tehran, Iran
}

Received: 21 February 2021

Accepted for publication: 15 May 2020

[EPub a head of print-31 May 2021]

Payesh: 2021; 20 (3): 275-284

\begin{abstract}
Objective (s): Access to relevant information is the basis for making the right decision and choice. However, people have very little information about the structures, processes and outcome of hospitals and the quality, price and efficiency of services provided. The experiences of other countries have shown that the first step to move towards transparency is the tendency and determination of the authorities. This research then aimed to measure the tendency of hospital managers to be transparent in disclosing information to public.

Methods: The present study was an applied descriptive study using survey method. A questionnaire was developed by research team and used after confirming the face and content validity as well as its reliability. This questionnaire was completed by 310 senior, middle and operational managers of genral public hosptials affilated to Tehran University of Medical Sciences (TUMS). Data analysis was performed using SPSS software.

Results: The highest tendency of participants was towards information transparency related to the structural indicators and the lowest was in outcome indicators of hospitals. Management level, organizational position and level of education showed significant relationship with the tendency to transparency in its various dimensions.

Conclusion: Hospital managers have a relatively strong tendency for transparency of information in the general public hospitals. Taking knowledge of the priorities and desires of managers, policymakers might be able to identify the disclosable performance indicators. Public disclosure of less sensitive indicators (i.e. structural indicators) might pave the way for the transparency practices.
\end{abstract}

Key Words: Transparency, Open Access Dataset, Hospital Administrator

\footnotetext{
* Corresponding author: School of Public Health, Tehran University of Medical Sciences, Tehran, Iran

E-mail: me.mazinani@gmail.com
} 


\section{تمايل به شفافيت در مديران بيمارستانهاى دانشكاه علوم بزشكى تهران}

ابراهيم جعفرى يويان'، على محمد مصدق راد'، مريم مزينانى I

ا. دانشكده بهداشت، دانشعاه علوم يزشكى تهران، تهران، ايران

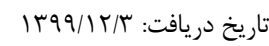

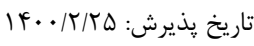

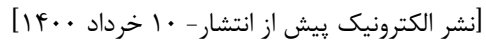

نشريه קايش:

مقدمه: دسترسه بـ به اطلاعات متناسب اساس تصميم گيرى و انتخاب صحيح است. با اين وجـود، مـردم اطلاعـات بسـيار انـدكى از سـاختارها،

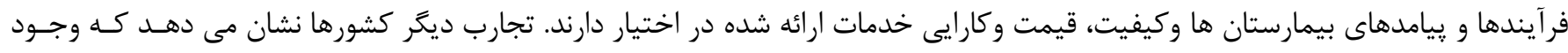

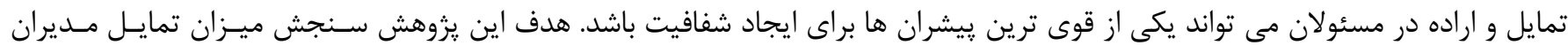

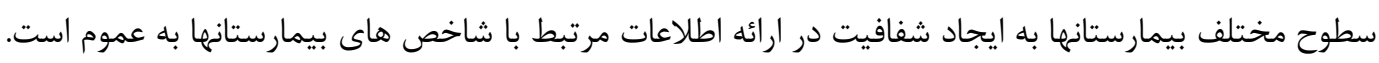

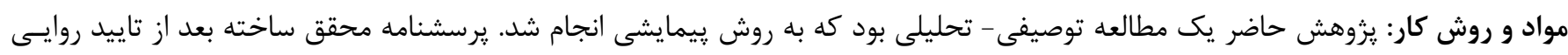

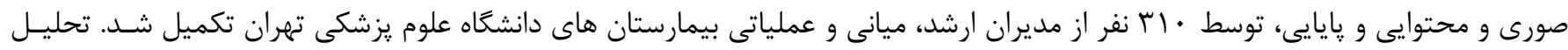
داده ها با كمك نرم افزار محتى

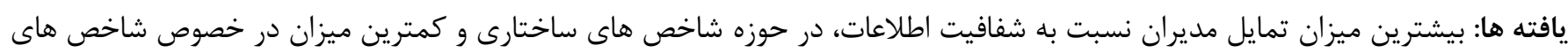

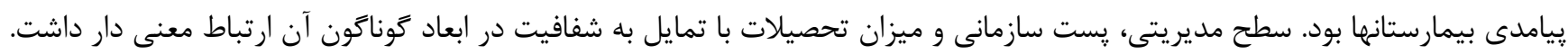

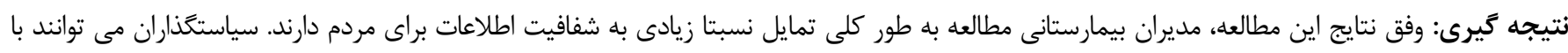

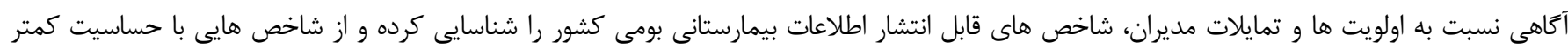
فرآيند شفافيت رادر كشور آغاز كنند. كليدوازه: شفافيت، دسترسى آزاد به اطلاعات، مديران بيمارستان 
كاهش قابل توجه يرونده هاى قصور يزشكى ، كـاهش هزينـه هـاى دادرسى و يك محيط امن تر شود [9].

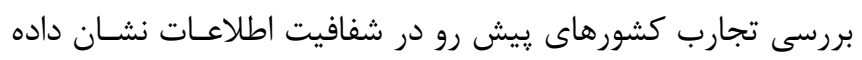

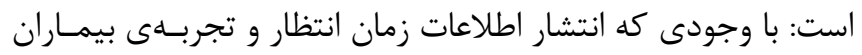

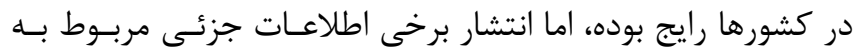

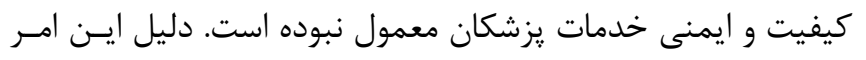

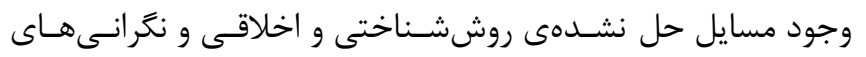

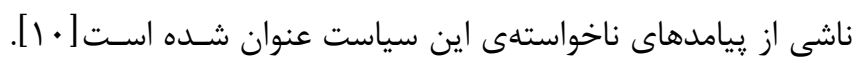

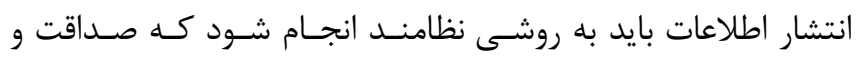

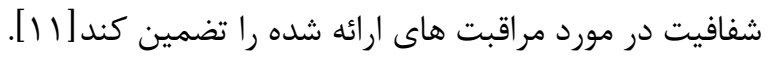

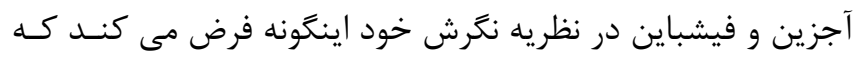

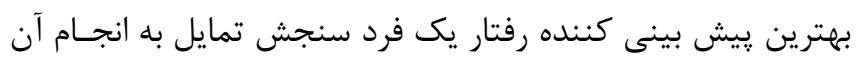

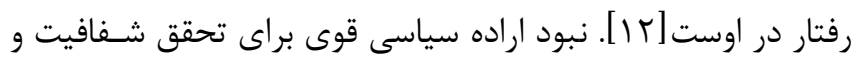

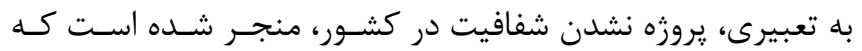

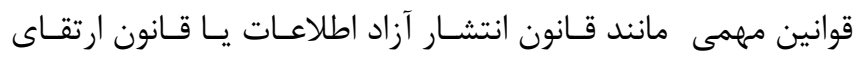

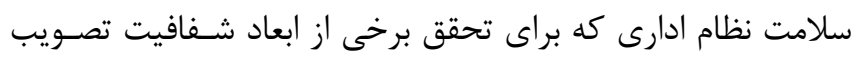

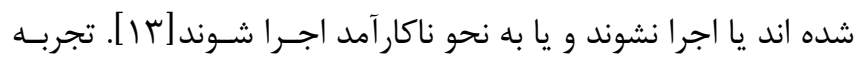

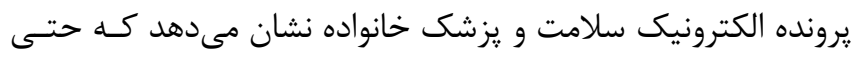

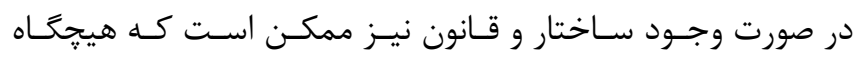

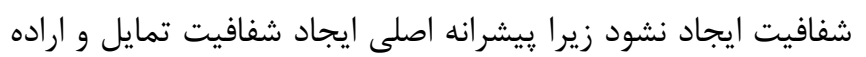

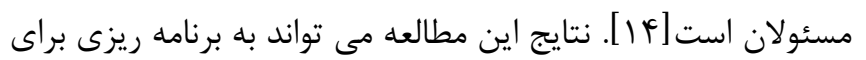
ارتقاى شفافيت اطلاعات در نظام سلامت ايران كمك كند.

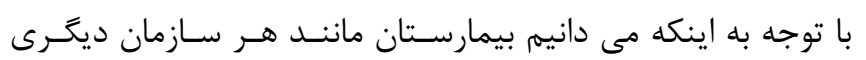

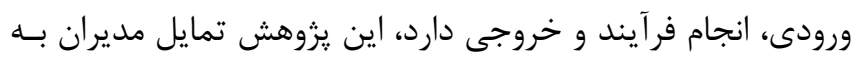

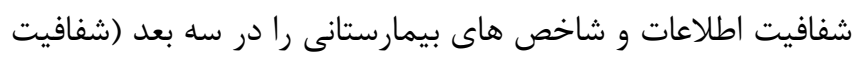

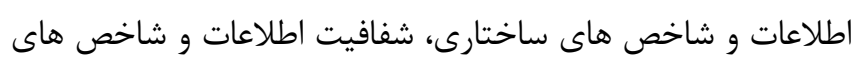

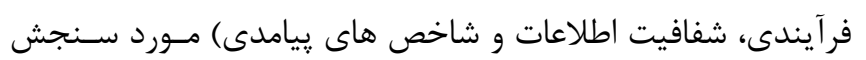

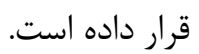

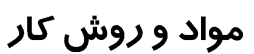

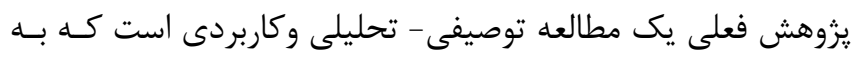

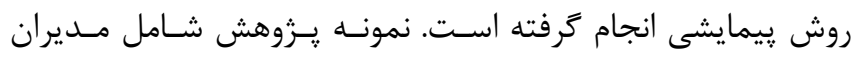

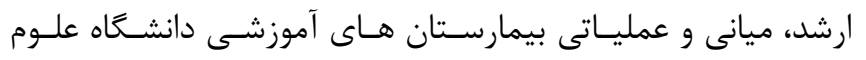

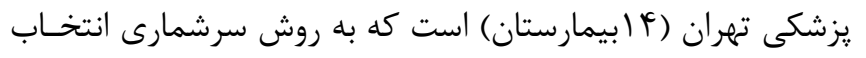

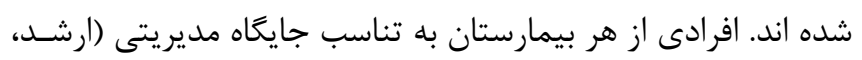

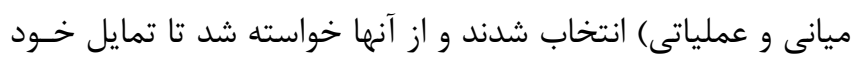

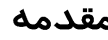

شفافيت از كذشـته، يـك نيـاز عمـومى بـراى جوامـع دموكراتيـك

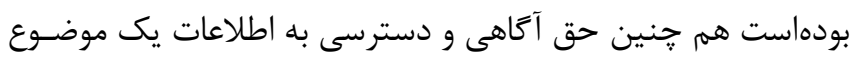

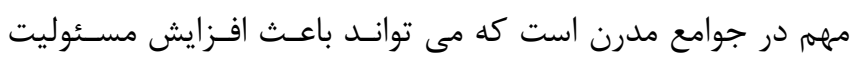

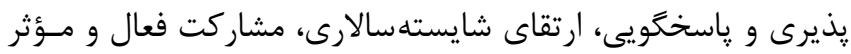

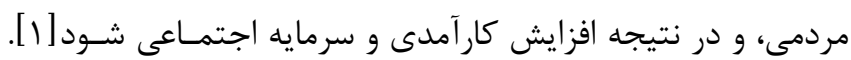

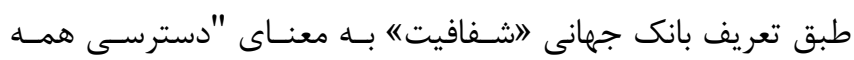

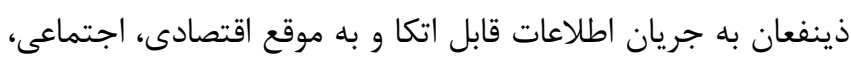

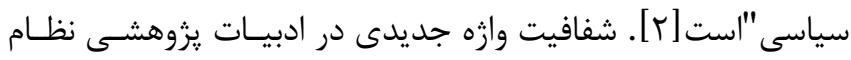

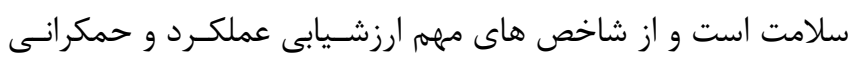

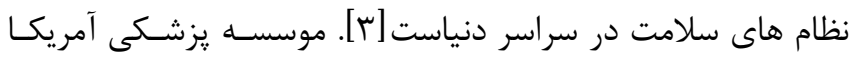

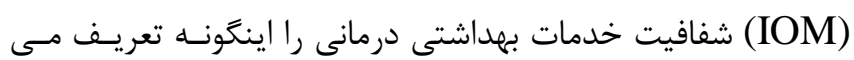

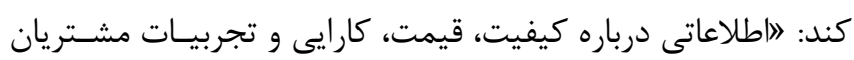

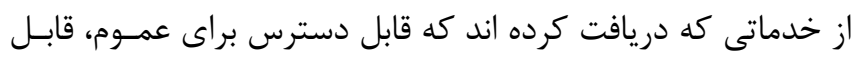

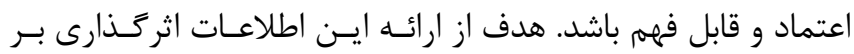

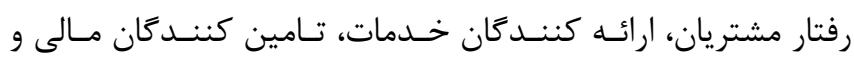

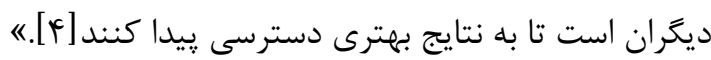

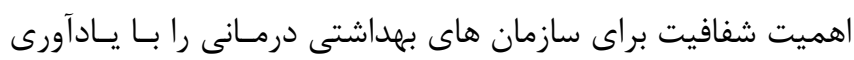

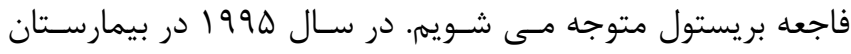

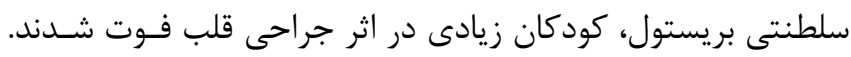

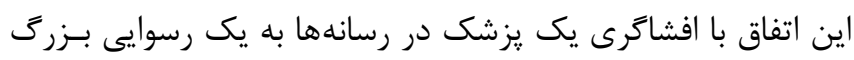

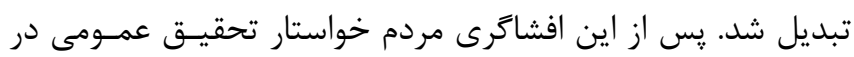

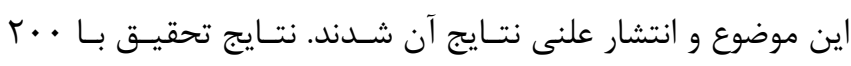

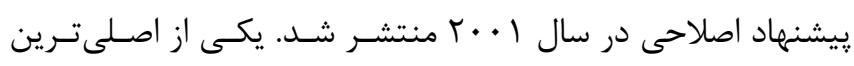

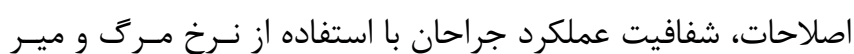

بود [ه].

ضرورت يرداختن به شفافيت از توجه به آثـار و نتـايج آن مشـخص مى شود. تجربيات نظام طب ملى انعلستان (NHS) و ساير كشـورها

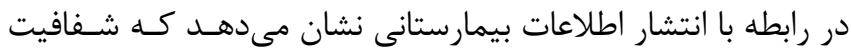

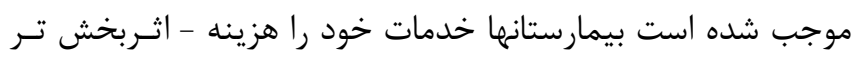

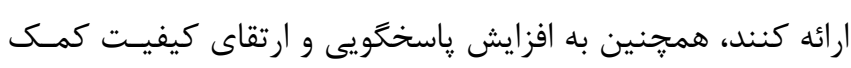

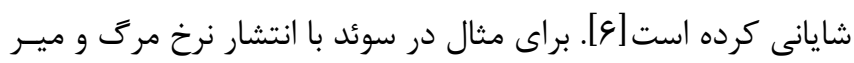

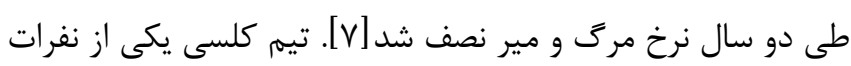

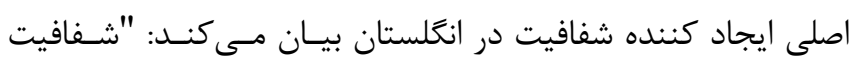

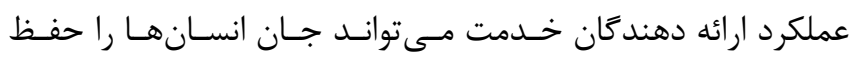

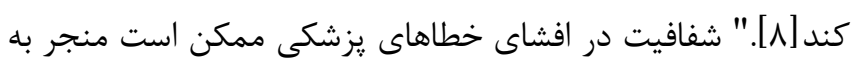


جهت اطمينان از اينكه مهمترين و صحيح تـرين محتـوا (ضـرورت

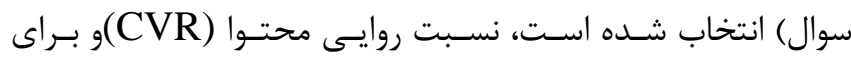

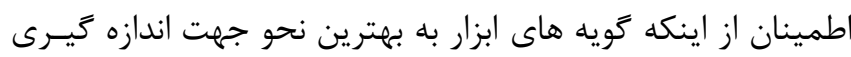

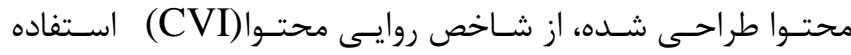

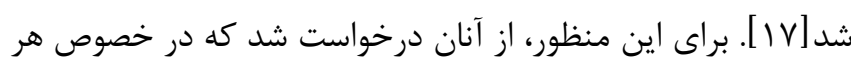

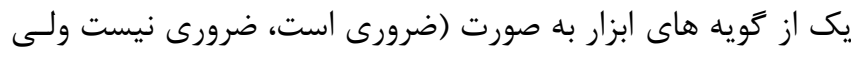

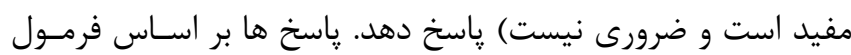
(CVR)

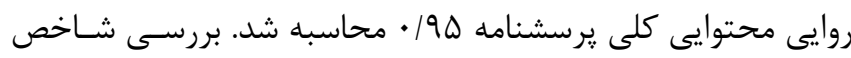

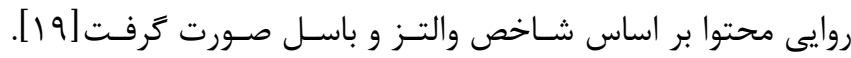

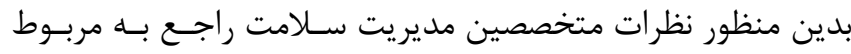

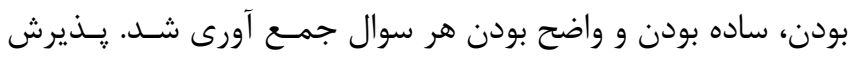

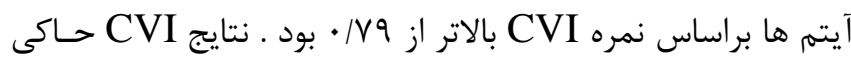

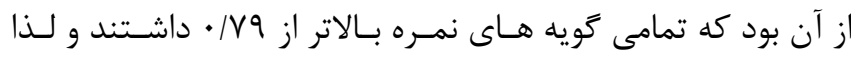

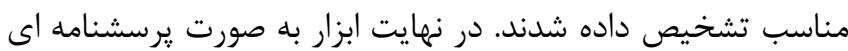

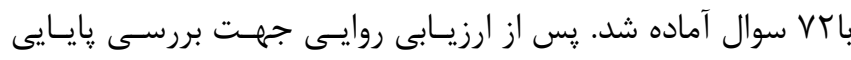

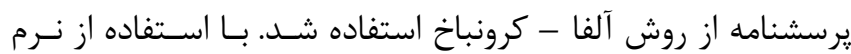

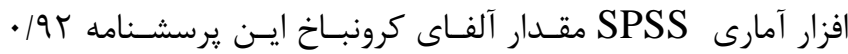

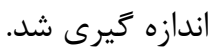

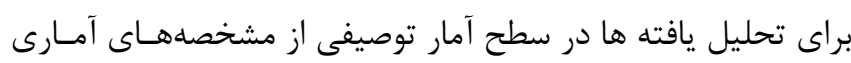

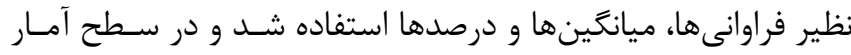

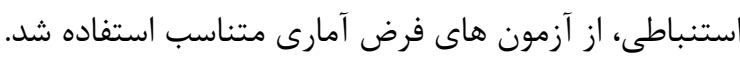

\section{يافتهها}

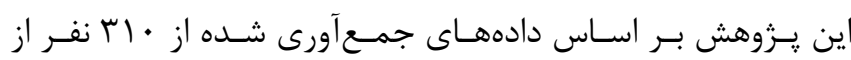

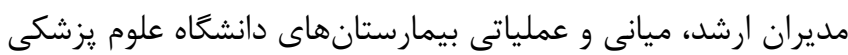

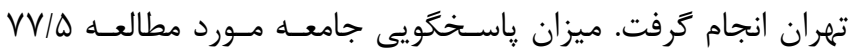

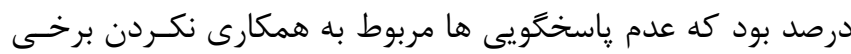

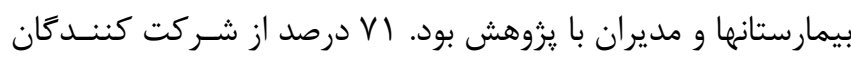

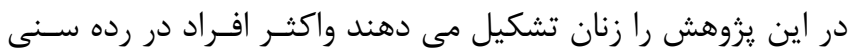

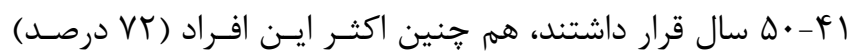

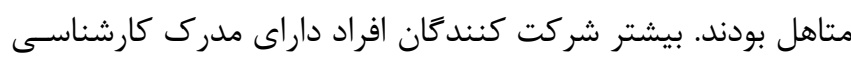

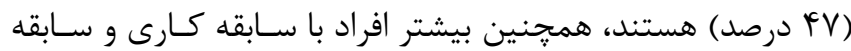

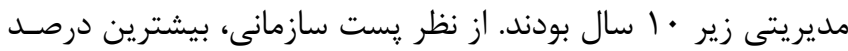

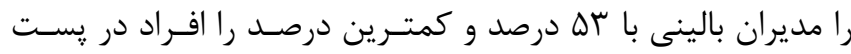

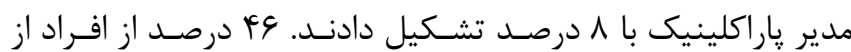

را به نسبت بـه شـفاف سـازى اطلاعـات مختلـف بيمارسـتان خــود

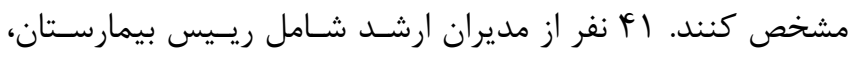

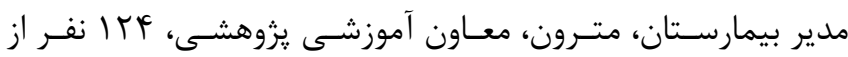

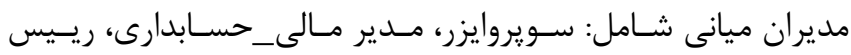

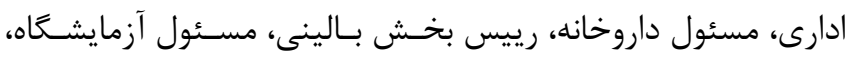

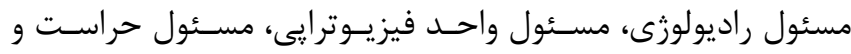

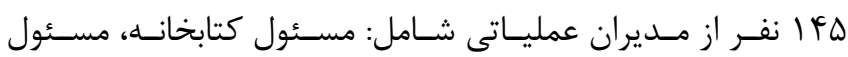
دبيرخانه، مسئول تاسيسات، مسئول روابط عمومى، مسئول بهداشت محيط_حرفه اى، مسئول واحد تغذيه، مسئول واحد بهبود كيفيـت،

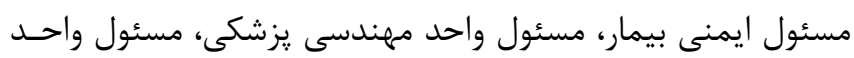

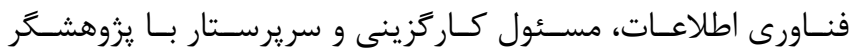
همكارى كرده و يرسشنامه را تكميل كردند.

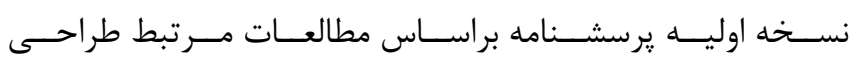

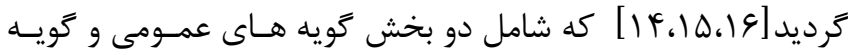
هاى اختصاصى بود. كويه هاى عمومى مربوط به متغيرهاى زمينهاى

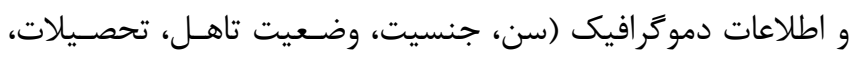
بست سازمانى، سابقه كار، سابقه مـديريت و سـطح مـديريتى) بـود.

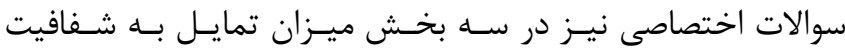

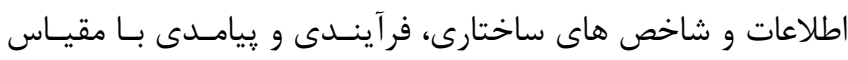

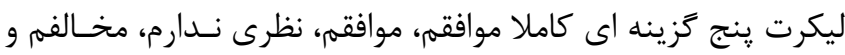

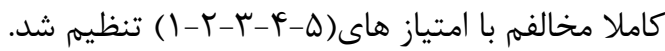

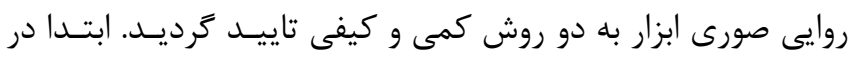

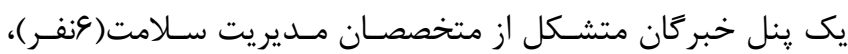

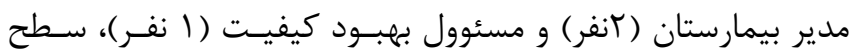

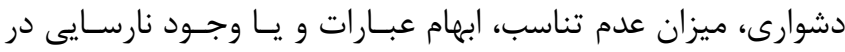

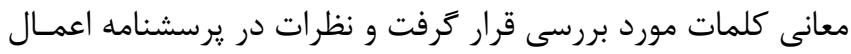

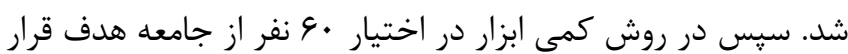

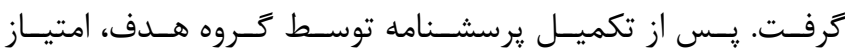
تاثير (Impact Score) محاسبه شد (1/9).

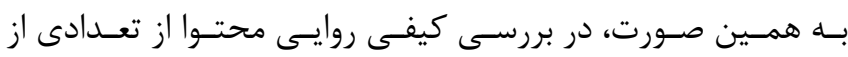

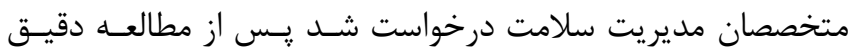

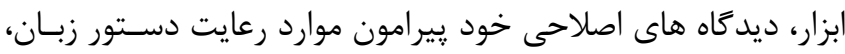

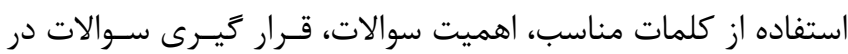
جاى مناسب خود و زمان تكميل يرسشنامه را به صورت كتبى ارائه نمايند. پِ از جمع آورى نظرات متخصصان، تغييرات لازم در ابـزار

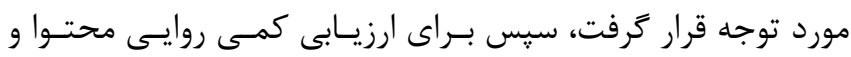


ميزان عدم تمايل به شفافسازى اطلاعات در بعد يِامدى بيشـتر از

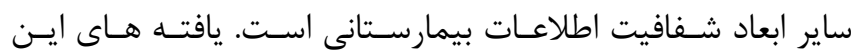

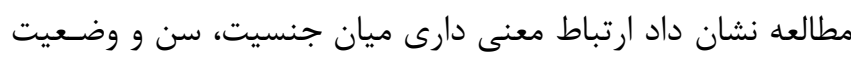

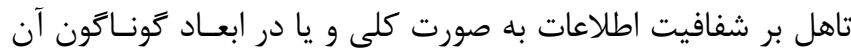

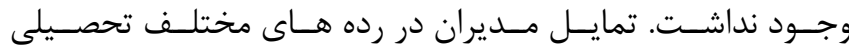
(كارشناسى، كارشناسى ارشد، دكترى، متخصص و فوق تخصص) به

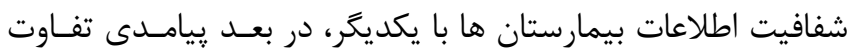

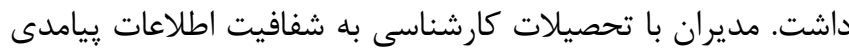

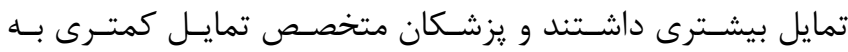
شفافيت اين اطلاعات نشان دادند. افراد حاضر در اين مطالعه از نظر يست سازمانى به سه گَروه مديران بالينى، مديران پاراكلينيك و مديران يشتيبانى-ادارى-مالى تقسيميم

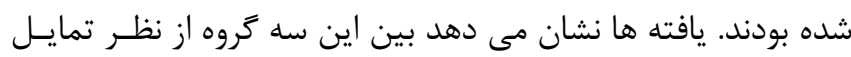
كلى به شفافيت اطلاعات تفاوت هايى وجود داشت. بيشترين ميـزان تمايل به شفافيت در گروه مديران بـالينى و كمتـرين آن در كَروهات

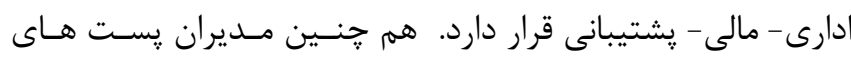

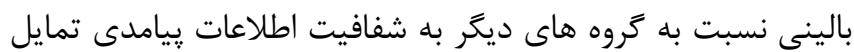
بيشترى داشتند. يافته هاى اين يزوهش نشان داد كه تمايل به شـفافيت (بــهـ صـورت إنـان

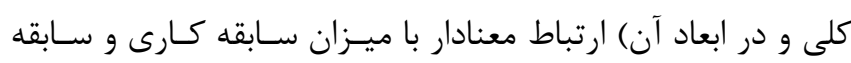

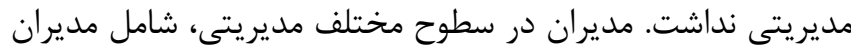

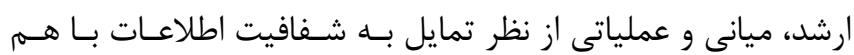

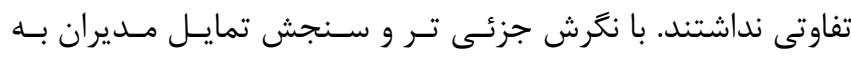
شفافيت اطلاعات در هر كـدام از ابعـاد آن مسى بينـيم كـهـ مـديران عملياتى به شفافيت اطلاعات ييامدى تمايل بيشترى داشتند.
مديران عملياتى هستند و با درصـد از مـديران ارشـــ كـهـ در ايـن

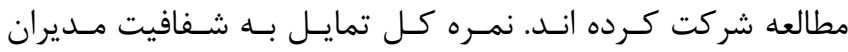

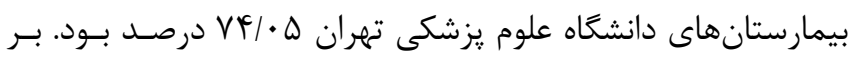

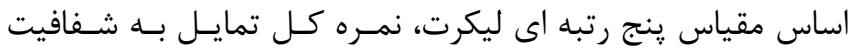

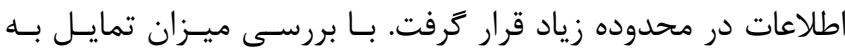

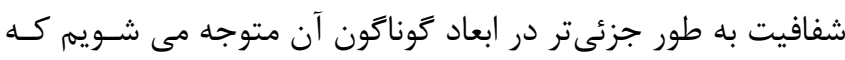

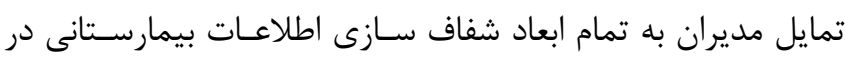

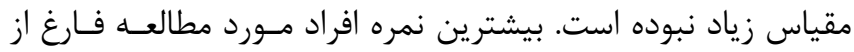

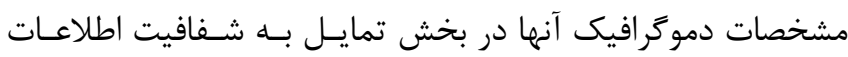

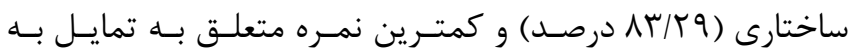

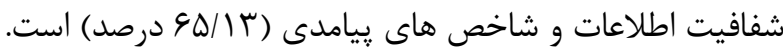

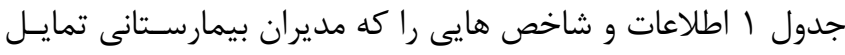

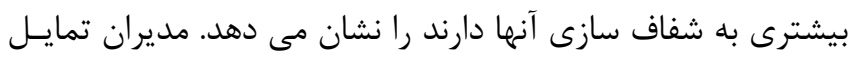

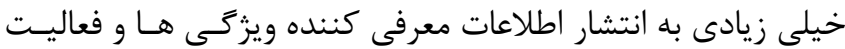

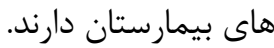
جدول r اطلاعات و شاخص هايى را كه مــديران بيمارسـتانى تمايـل كمترى به شفاف سازى آنها دارند را نشان مى دهد. شبكه مـدير كاريتى

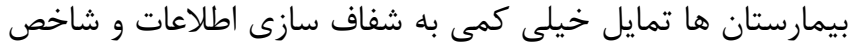
هاى مربوط به مركى و مير، ايمنى بيمار، تعرفه ها و اطلاعات سـرانه يرسنل براى عموم مردم دارند.

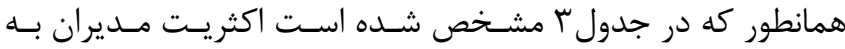
شفافسازى اطلاعات ساختارى تمايل خيلى زيـادى دارنـد. مقايسـهـ

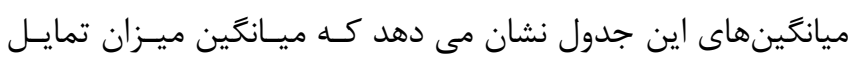

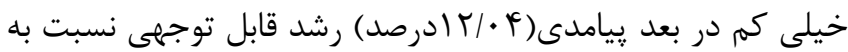

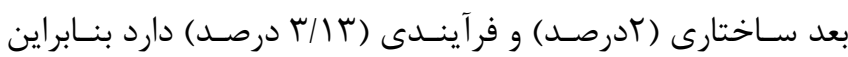


سال بيستم، شماره سوم، خرداد ـ تير If..

نشريه يروهشكده علوم بهداشتى جهادانشعاهى

جدول ا: بيشترين ميزان تمايل شبكه مديريتى بيمارستانها نسبت به شفافيت اطلاعات و شاخصها

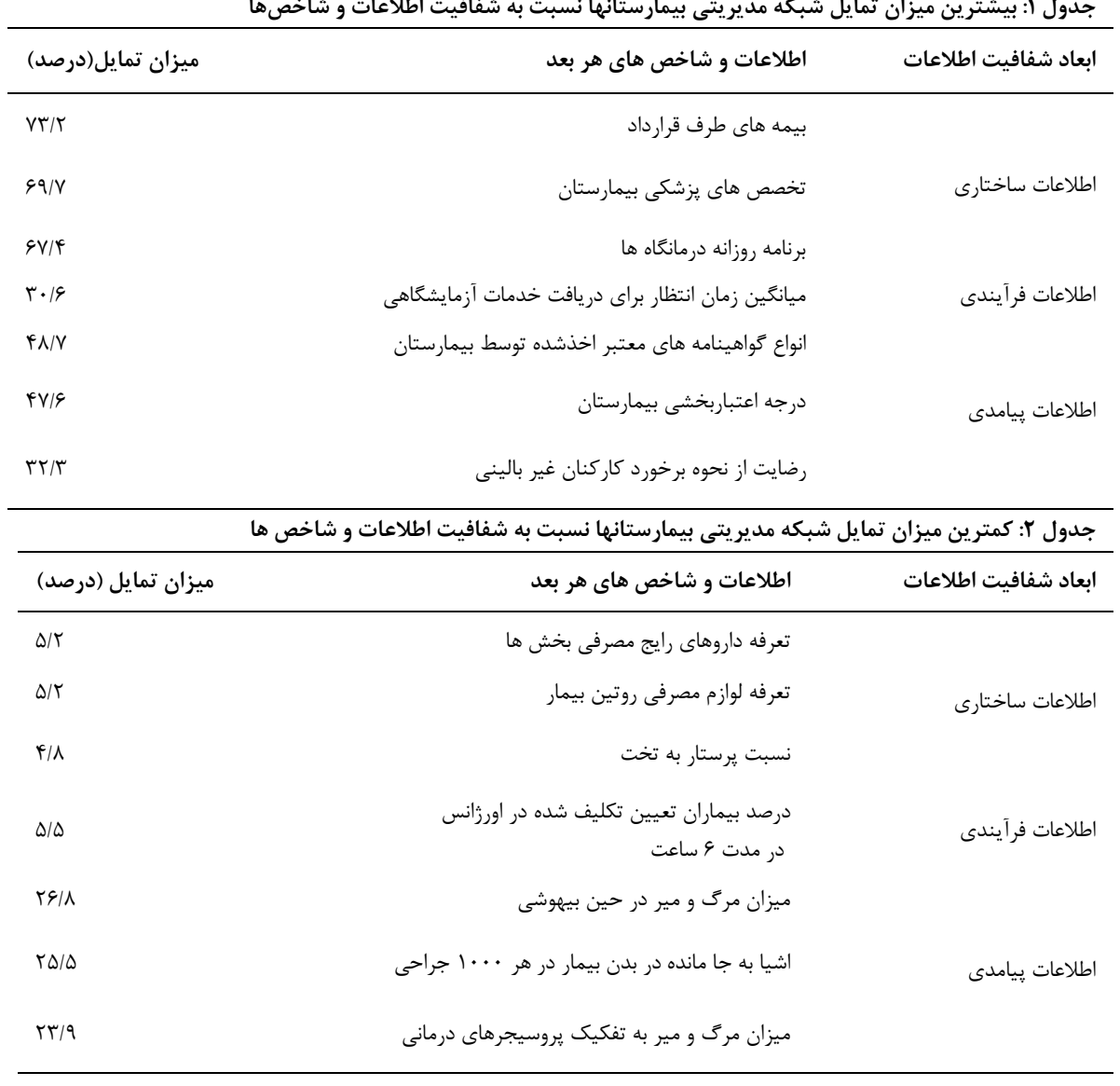

جدول ب: ميانغين ميزان تمايل به شفافيت مديران (درصد)

\begin{tabular}{|c|c|c|c|c|c|c|c|}
\hline ميانغين & انحراف معيار & خيلى كم & كم & متوسط & 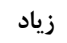 & خيلى زياد & ابعاد شفافيت اطلاعات بيمارستانى \\
\hline$\varphi / 1$ & $\cdot / 9$ & r & $\Delta / \Lambda$ & $10 / 1$ & T\&/G & $49 / 1$ & اطلاعات و شاخص هاى ساختارى \\
\hline$r / 9$ & $1 / \cdot$ & $r / 1$ & $\Lambda / V$ & rq/q & $r r / q$ & $r \Delta / \varphi^{\top}$ & اطلاعات و شاخص هاى فرآيندى \\
\hline$r / T$ & $1 / 1$ & $\mid r / \cdot F$ & $|f / 9|$ & TI/Af & TV & $19 / 90$ & اطلاعات و شاخص هاى بيامدى \\
\hline
\end{tabular}

به جه دليل مطالعات ديخر حاكى از عدم شفافيت در نظام سلامت و

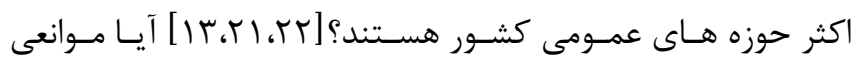

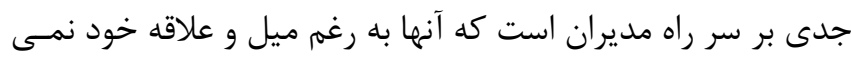

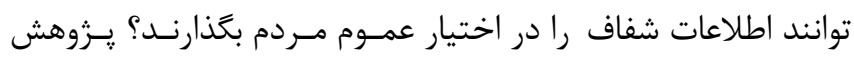

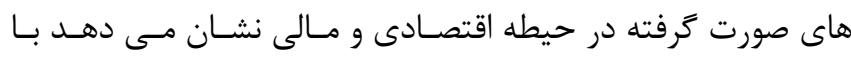

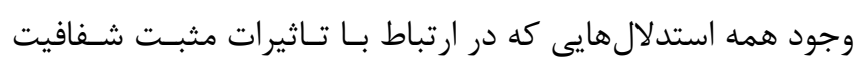

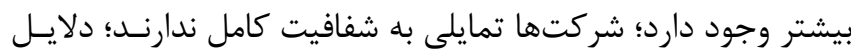

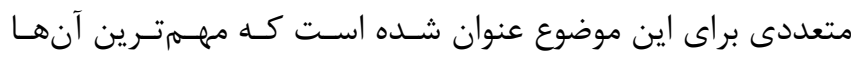

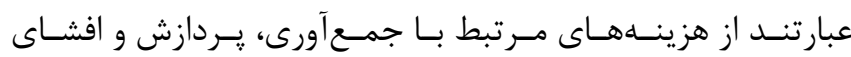

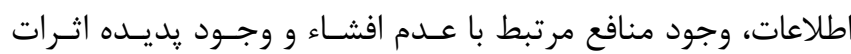

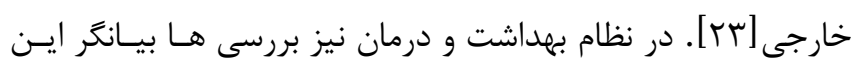

\section{بحث و نتيجه تيرى}

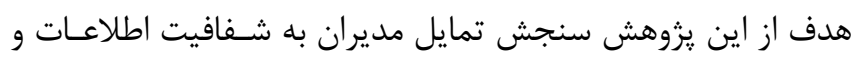

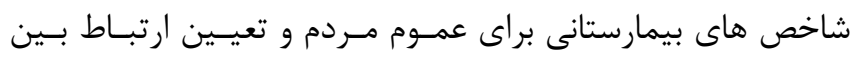

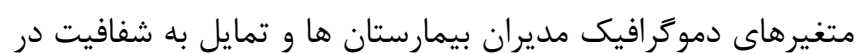

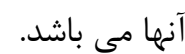
يافته هاى اين مطالعه نشان مى دهد كه تمايل مديران به شـافيت بـافيت

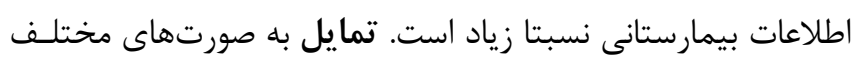
براى نشان دادن شروع فعاليت عمدى، حالت ذهنى همراه با ميل به

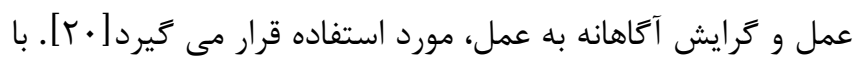

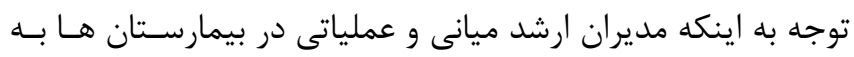

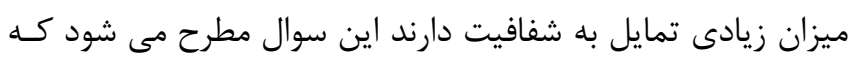


مراكز تحت يوشش آنها ايسن اطلاعـات بايسـد بـه صـورت بـهـ روز در اختيار مردم قرار گيرد. اين موارد احتمالا رايج تـرين سـوالات افـراد

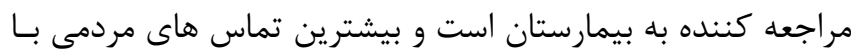
مراكز درمانى و مراجعه به وبعاه هاى اينترنتى براى يافتن ياسخ اين

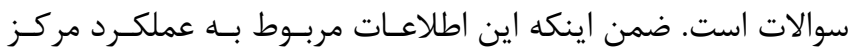

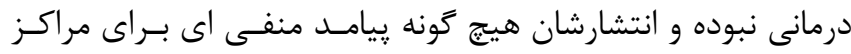

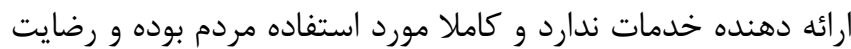

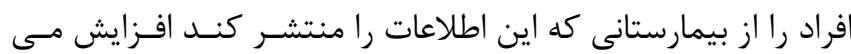
دهد. يافته ها نشان دادند مديران بيشتر تمايل دارند كه بيمارسـتان إنسان

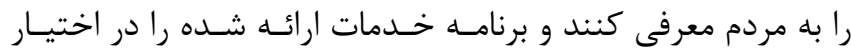
مردم قرار دهند. مى توان شفاف سـازى اطلاعـات بيمارسـتانى را از

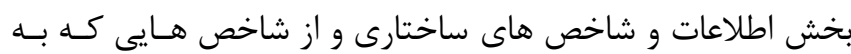
معرفى بيمارستان مى يردازند شروع كرد.

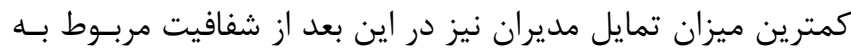

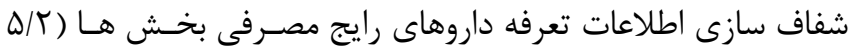

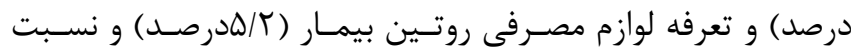

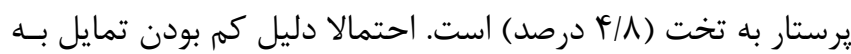

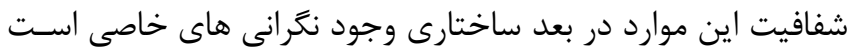

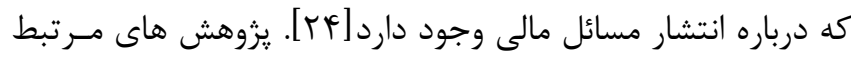
نشان داده است شفافيت مالى مى تواند اعتماد مشتريان را بــهـ ارائسه

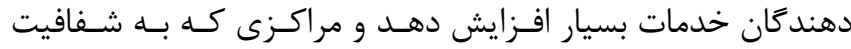

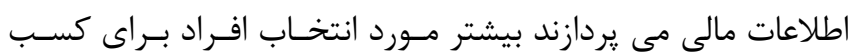

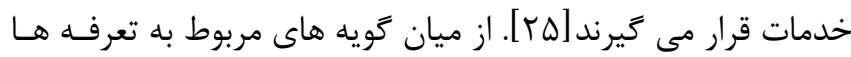
نيز مديران حساسيت كمترى نسبت به شفاف سازى تعرفه يك شب ميب مريك بسترى استاندارد و تعرفه عمل هاى جراحى داشتند كـهـ مـى تـوان

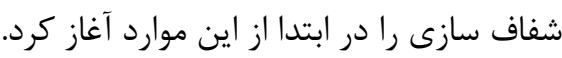

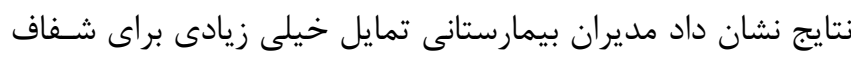
سازى ميانگين زمان انتظار براى دريافت خدمات آزمايشعاهى دارنـد و خيلى كم مايل هستند تا درصد بيمـاران تعيـين تكليـف شـده در اورزانس در مدت 9 ساعت را براى عموم مردم شفاف سـازى كنـــد.

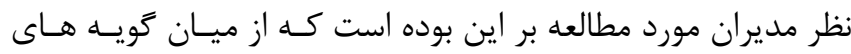

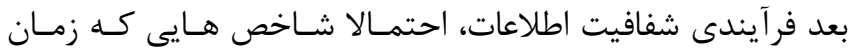
انتظار را به مردم نشان مى دهد بيشتر مورد استفاده بـوده و تمايـل براى شفاف سازى آنها بيشتر است. عدم تمايل مديران به شفافيت در بعد يِيامـدى مـى توانـد ناشـى از

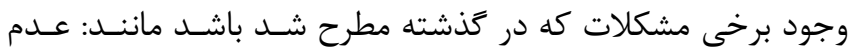

است كه شفافيت به ميزان لازم موجود نيست و بيمارستانهاى ما از

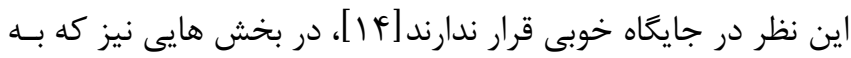

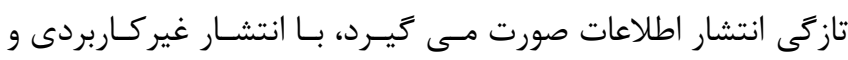
غيرشفاف اطلاعات رو به رو هستيم. يزوهش هاى مرتبط بيـان مسى اسى كنند كه با وجود تصويب قانونهاى ايجاد شفافيت، بدليل نبود عـزم

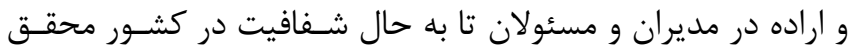

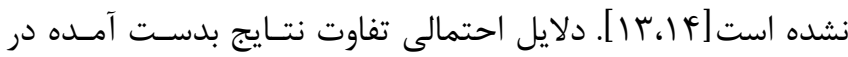
اين يزوهش با واقعيت هاى موجود و ديگر مطالعـات در ايـن زمينــه

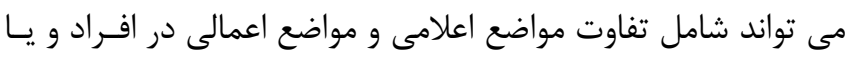

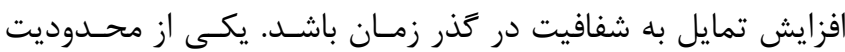
هاى يزوهش كمى را مى توان در عدم دستيابى به حقيقت باورهـا و

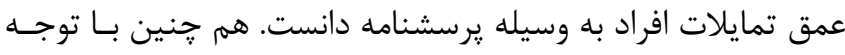

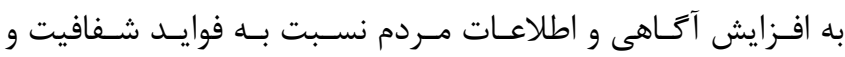
مطالبات مردمى كه در حيطههاى گوناگون مسائل كشـور مبنـى بـر

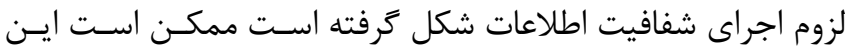

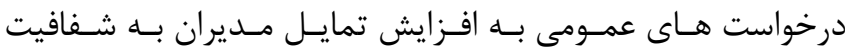

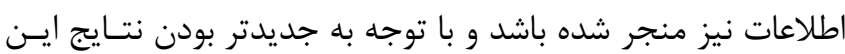
يزوهش با مطالعات مقايسه شده مى توان اين تفاوت را توجيه كرد. با بررسى ميزان تمايل به شفافيت به طور جزئى تر در ابعاد گونـاتون

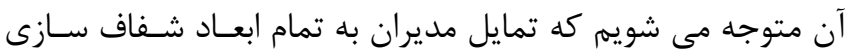

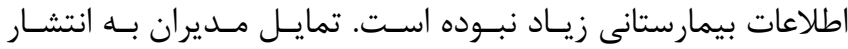

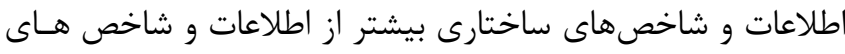
فر آيندى و ريامدى است.

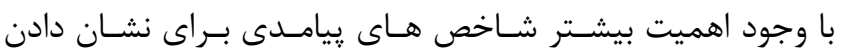
كيفيت خدمات و بهره ورى در يك بيمارستان نتايج نشان مى دهـد

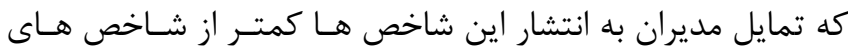

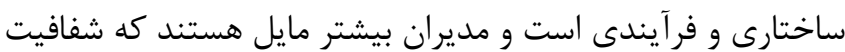
براى اطلاعات بـى خطــر (شـاخص هــاى سـاختارى) محقـق شـود.

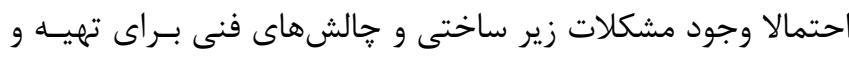

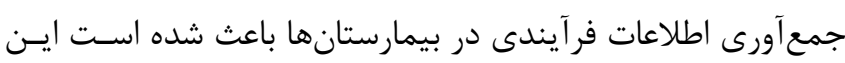
اطلاعات به صورت شفاف منتشر نشود. در بعد شفافيت اطلاعـات سـاختارى، بيشـترين تمايـل مـديران بــهـ

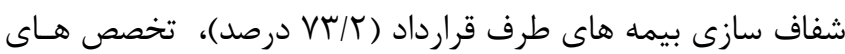

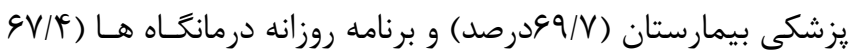

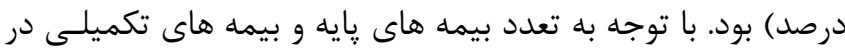

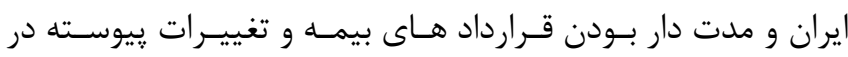


نشريه يثروهشده علوم بهداشتى جهاددانشگاهى

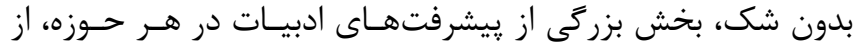

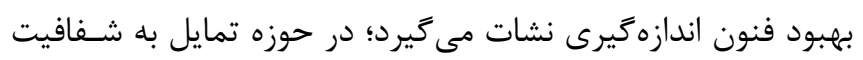

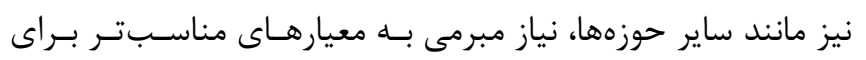

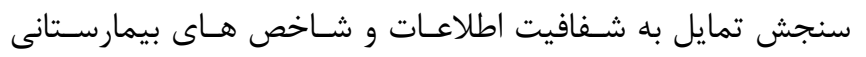

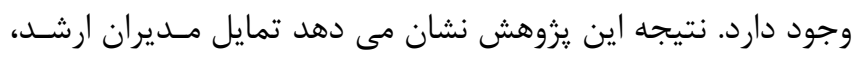

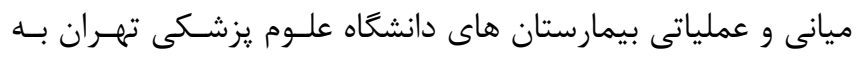

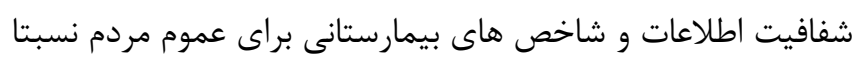

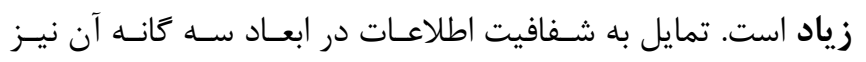

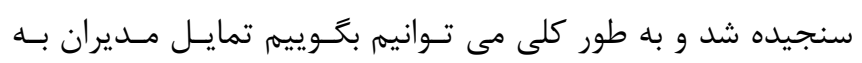

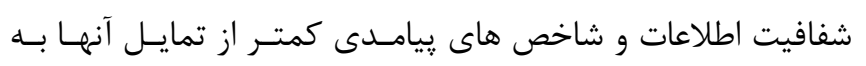

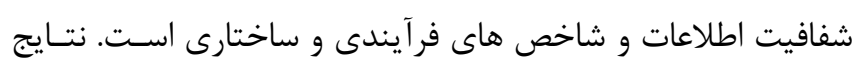

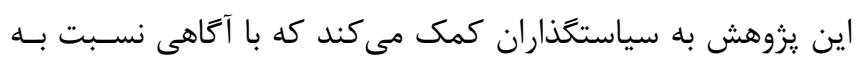

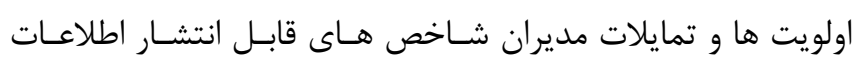

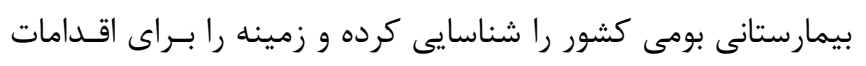

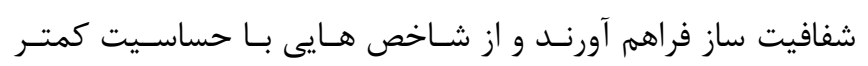

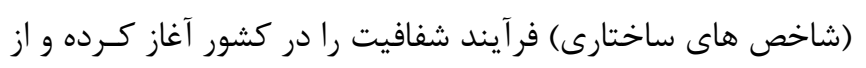
فوايد آن بهره مند شوند.

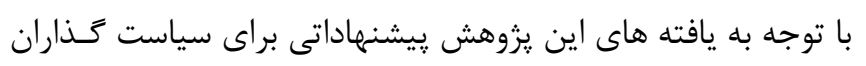

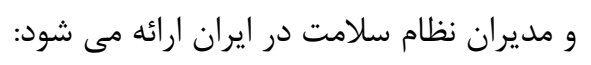

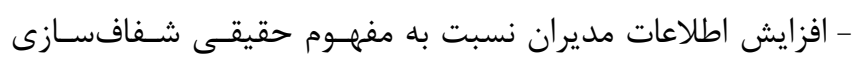

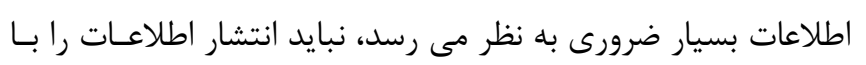

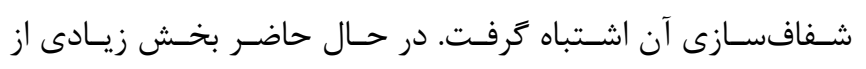

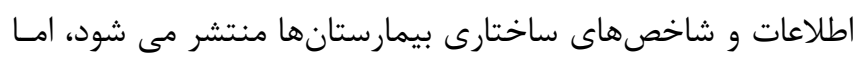

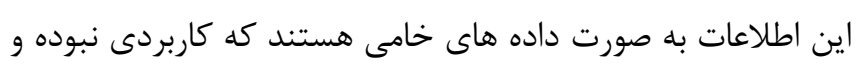

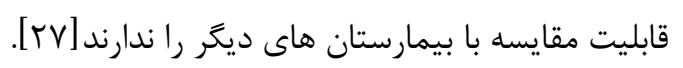
- با همكارى متخصصان در زمينه فنـاورى اطلاعـات و كارشناسـان

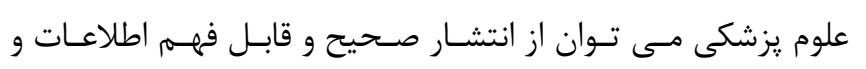

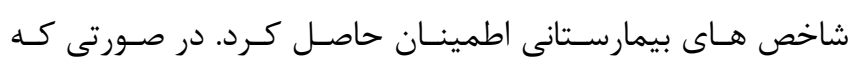

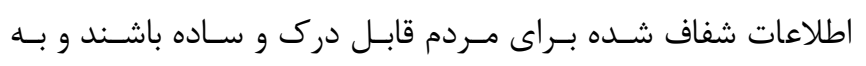

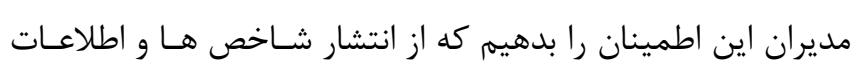

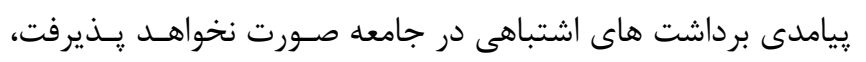

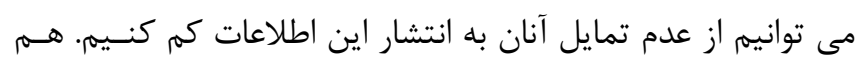

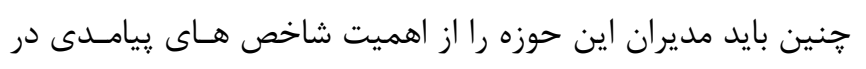

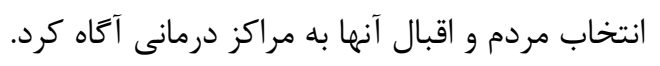

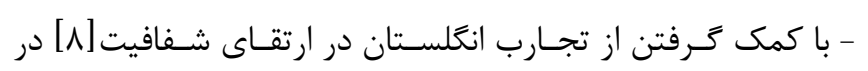

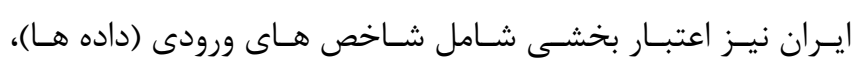

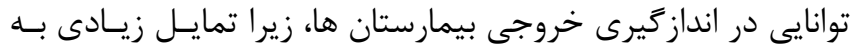

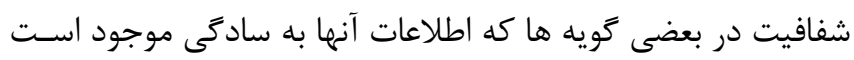

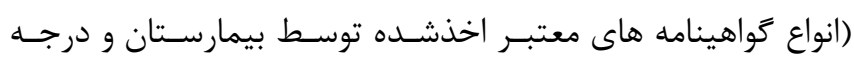
اعتباربخشى بيمارستان) در بين مديران وجود داشت مدئ.

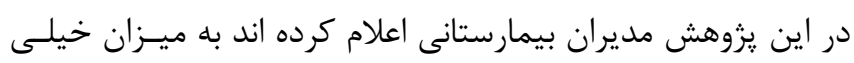

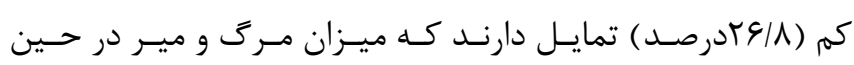

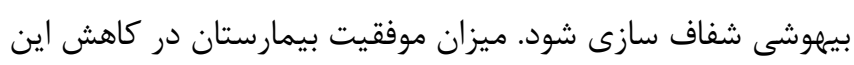

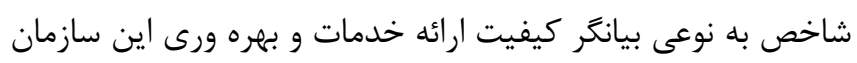

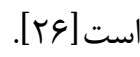

مديران شركت كننده در اين يزوهش مايل به شفاف سازى اطلاعات

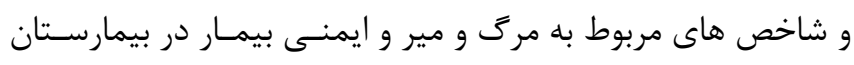

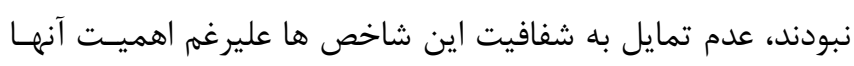

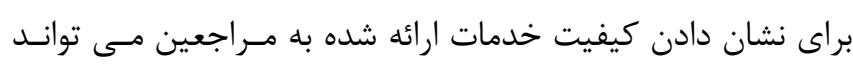

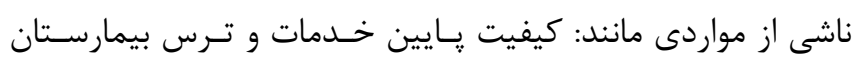

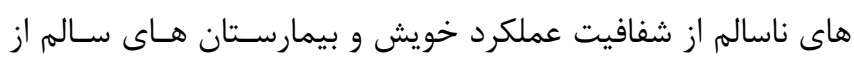

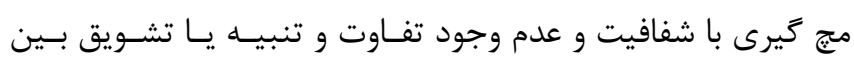

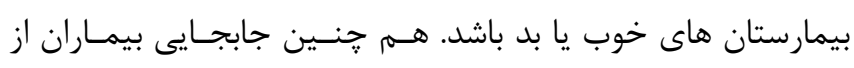

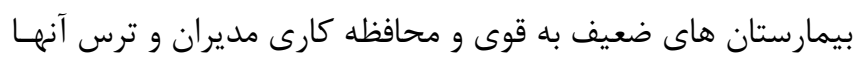

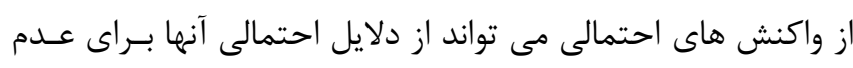

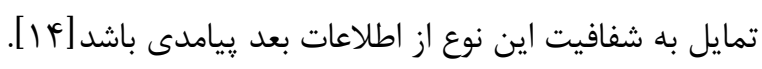

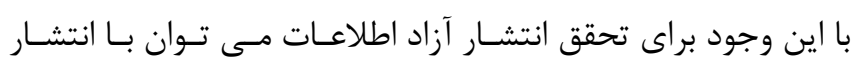

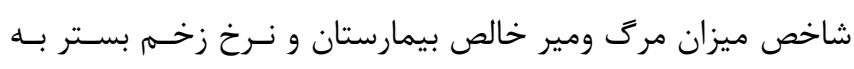

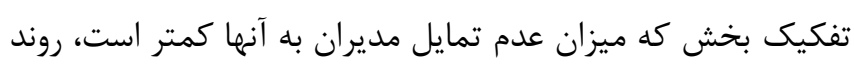
شفافيت رادر كشور آغاز كرد.

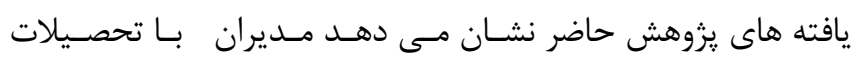

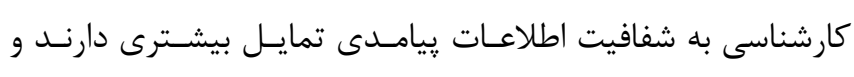

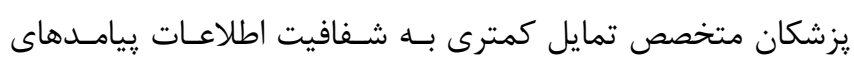

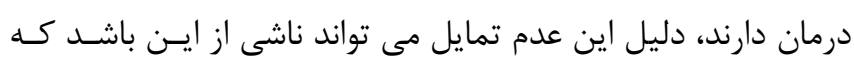

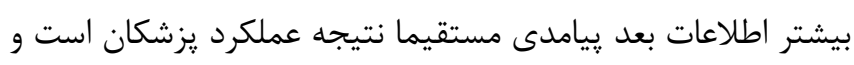

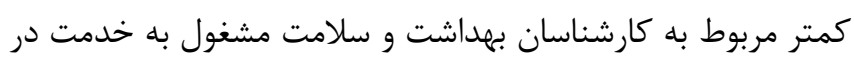

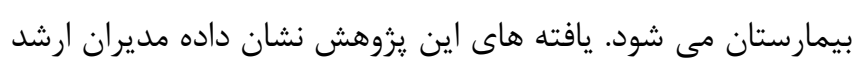

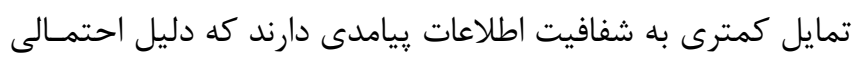

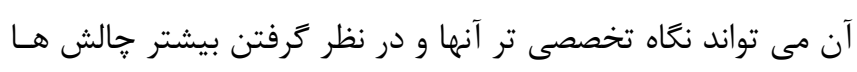

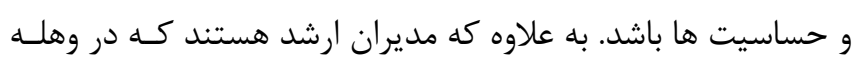

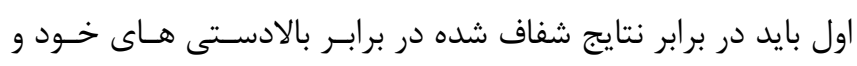
مردم پِاسخكو باشند، نه مديران عملياتى و ميانى. 


$$
\text { على محمد مصدق راد: طراحى يزوهش، مشاور علمى }
$$

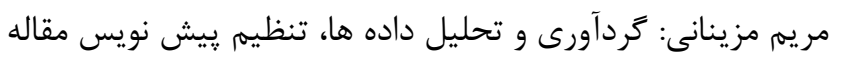

\section{تشكر و قدردانى}

اين مقاله بركرفته از پايــان نامـه كارشناسـى ارشد رشـته مـديريت

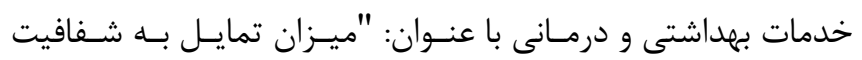

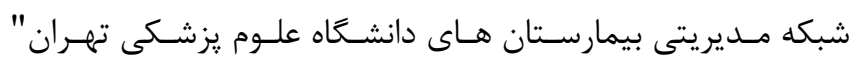

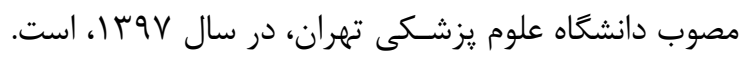

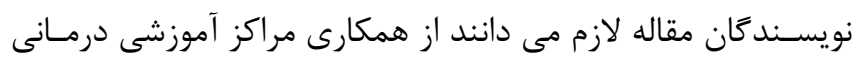

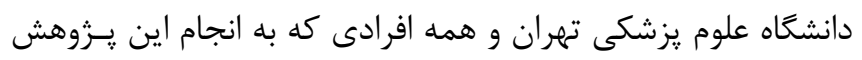
كمك كردند، تشكر و قدردانى كنند.

\section{منابع}

1. Transparency for Iran. https://tp4.ir/transparencyfor-iran/2019. [Available from: February 17, 2021.]

2. Bellver A, Kaufmann D. Transparenting transparency: Initial empirics and policy applications. World Bank Policy Research Working Paper Journal 2005;20: 52-72

3. Mosadeghrad AM, Rahimitabar P. Health system governance in Iran: A comparative study. Razi Journal of Medical Sciences 2019; 26: 10-28 [In Persian].

4. Kirschner N, Ejnes Y, Tape GT, Auted AM, Fihn SD, Hatton D. Healthcare Transparency-Focus on price and clinical performance information. American College of Physicians a Policy Paper 2010; https://www.acponline.org/system/files/documents/ad vocacy/current_policy_papers/assets/transparency_iss ues_brief.pdf

5. Inquiry BR, Kennedy I. the report of the public inquiry into children's heart surgery at the Bristol Royal Infirmary 1984-1995. Stationery Office 2001; [Available from: https://navigator.health.org.uk/theme/report-publicinquiry-childrens-heart-surgery-bristol-royalinfirmary]

6. Henke N, Kelsey T, Whately H. Transparency, the most powerful driver of health care improvement? McKinsey's Health Systems and Services Practice 2011; 11:1-10

7. Larsson S, Lawyer P, Silverstein M. From concept to reality: putting value-based health care into practice in Sweden. The Boston consulting Group Journal 2010 [Available from:

$$
\begin{aligned}
& \text { فر آيندى و ييامدى است و از ميان اين شاخص ها مى توان با توجـهـ }
\end{aligned}
$$

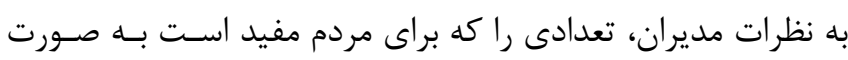

$$
\begin{aligned}
& \text { شفاف منتشر كرد. }
\end{aligned}
$$

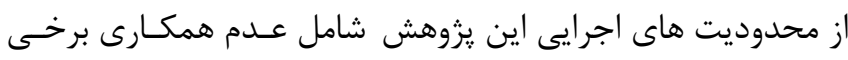

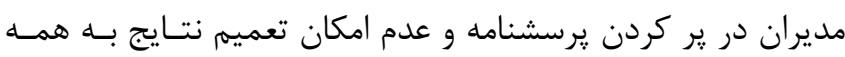

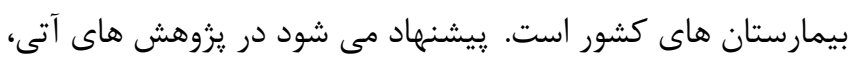

$$
\begin{aligned}
& \text { اطلاعاتى كه انتشار شفاف آنها مورد تمايل مصرف كنند }
\end{aligned}
$$

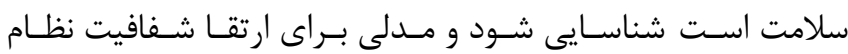

$$
\begin{aligned}
& \text { سلامت ايران طراحى شود. } \\
& \text { سهم نويسند تان } \\
& \text { ابراهيم جعفرى يويان: طراحسى يـرزوهش، جمـع آورى داده، تحليـل } \\
& \text { داده، هدايت تنظيم و اصلاح مقاله }
\end{aligned}
$$

https://www.bcg.com/publications/2011/biopharmahealth-care-payers-providers-health-care-fromconcept-to-reality]

8. Kelsey T. Transparency in the NHS not only saves lives - it is a fundamental human right. The Guardian 2013. [Available from:

https://www.theguardian.com/society/2013/mar/12/nh s-transparency-open-data-initiative:/]

9. Donn SM, McDonnell WM. When bad things happen: adverse event reporting and disclosure as patient safety and risk management tools in the neonatal intensive care unit. American Journal of Perinatology 2012; 29: 65-70

10. Rechel B, McKee M, Haas M, Marchildon GP, Bousquet F, Blümel M. Public reporting on quality, waiting times and patient experience in 11 highincome countries. Health Policy 2016; 120: 377-83.

11. Jonathan L Gleason, Eric Swisher, Patrice M Weiss. Obstetrics and Gynecology Clinics of North America 2019; 46: 247-255

12. VafaiNajar A, Masihabadi M, Moshki M, Ebrahimipour H, Tehrani H. Determining the theory of planned behavior's predictive power on adolescents' dependence on computer games. Iranian Journal of Health Education and Health Promotion2015; 2: 303311 [In Persian]

13. Explanatory Report on the Draft Transparency Bill. Tehran: Center for Strategic Mathematical Studies of the Republic, 2018 [Available from: http://css.ir/hgepvg] [In Persian] 
14. Bouzarjomihri H. Challenges and Solutions for Promoting Transparency for Hospitals in Iran [dissertation]. Tehran University of Medical Science 2017 [In Persian]

15. Rahmani A, Bashiri N. A Review of the Information Disclosure Literature in Iran. Accounting Research 2014; 15: 35-66 [In Persian]

16. Bouzarjomehri H, Akbari Sari A, Jaafari Pooyan E. Comparative Study of Hospitals' Transparency in Eight Countries. Hakim Research Journal 2019; 22: 273-283 [In Persian].

17. Boparai GK Singh S Kathuria BP. Wow to Design and Validate A Questionnaire: A Guide. Current Clinical Pharmacology 2018; 13: 210-215

18. Lawshe $\mathrm{CH}$. a quantitative approach to content validity. Personal Psychology 1975; 28:563-575

19. Waltz CF, Bausell RB. Nursing Research: design statistics and Computer analysis. $1^{\text {st }}$ Edittion,: W.B.Saunders Co: Philadelphia, 1981

20. Calhoun C. A dictionary of the social science. $1^{\text {st }}$ Edition, Oxford University Press: London, 2002

21. Transparency. The government's reasons for not making managers' salaries transparent. Fars press. [Available from: http://fna.ir/bs0xtd.]

22. Sadoughi F, Ershad Sarabi R, Valinejadi A. A Survey on Information Flow in Research Centers Affiliated with Tehran University of Medical Sciences. Journal of Health Administration 2014; 17: 43-50 [In Persian]
23. Arab Mazar A, Talebnia G, Vakilifard H, Samadi Lorgani M. Explaining the Relationship between Transparency of Financial Reporting and Tax Reporting in Iran. Accounting and Auditing Research 2011; 3: 22-37 [In Persian]

24. Yu-Hua Yan, Chih-Ming Kung. Transparency of Mandatory Information Disclosure and Concerns of Health Services Providers and Consumers. International Journal of Environmental Research and Public Health 2017;3:14

25. Badavar Nahandi Y, Pakmaram A. The impact of financial reporting quality on interaction between agency costs and speed of adjustment of stock price. Journal of Accounting Advances 2018; 10: 31-62

26. Eddy DM, Hollingworth W, Caro JJ. Model Transparency and Validation: A Report of the ISPORSMDM Modeling Good Research Practices Task Force-7. Medical Decision Making 2012; 32: 733-743 27. Bozarzomehri H, Sanaiy M. Transparency, EParticipation, and Open Government

New Methods for Government Rightsizing and Agility. Journal of Science and Technology Policy Lettersets 2019; 4:5-14 [In Persian] 